\title{
Pengaruh Kompetensi, Gaya Mengajar dan Motivasi terhadap Prestasi Mahasiswa
}

\section{The Effect of Competence, Teaching Style and Motivation on Student Achievement}

\author{
Gatot Kusjono* \& Suprianto \\ Program Studi Manajemen, Universitas Pamulang, Indonesia
}

Diterima: 02 Oktober 2020; Direview: 03 Oktober 2020; Disetujui: 18 Oktober 2020

*Coresponding Email:monatampu20@gmail.com

\begin{abstract}
Abstrak
Penelitian ini bertujuan untuk mengetahui pengaruh kompetensi, dan gaya mengajar dan motivasi terhadap prestasi mahasiswa di Universitas Pamulang. Populasi penelitian yaitu mahasiswa regular C semester ganjil 2019/2020 peserta perkuliahan mata kuliah statististik dan matematika ekonomi dosen peneliti yang berjumlah 247 responden, sedangkan sampel penelitian yang diambil sebanyak 72 reponden menggunakan rumus slovin. Metode penelitian yang digunakan deskriptif kualitatif dengan analisa data meliputi: uji instrumen (validitas dan reliabilitas), uji asumsi klasik, regresi linier berganda, uji F, uji t dan uji koefisien determinasi. Hasil penelitian diperoleh: 1) Kompetensi secara partial tidak berpengaruh terhadap prestasi mahasiswa; 2) Gaya mengajar dan Motivasi secara parsial berpengaruh terhadap prestasi mahasiswa; 3) Secara simultan kompetensi, gaya mengajar dan motivasi berpengaruh secara signifikan terhadap prestasi mahasiswa. Hasil ini sesuai dengan hasil uji $\mathrm{F}$, nilai Fhitung $(3,238)>$ dari Ftabel $(2,740)$ dengan signifikan 0,027 kurang dari 0,05.

Kata Kunci: Kompetensi, Gaya Mengajar, Motivasi, Prestasi
\end{abstract}

\begin{abstract}
This study aims to determine the effect of competence, teaching style and motivation on student achievement at Pamulang University. The study population was 247 respondents in the regular $C$ odd semester 2019/2020 students in statistics and economics courses, while the research sample was 72 respondents using the Slovin formula. The research method used is descriptive qualitative with data analysis including: instrument test (validity and reliability), classical assumption test, multiple linear regression, $F$ test, $t$ test and coefficient of determination test. The research results obtained: 1) Competence partially does not affect student achievement; 2) Teaching style and motivation partially influence student achievement; 3) Simultaneously competence, teaching style and motivation have a significant effect on student achievement. These results are in accordance with the results of the F test, the value of Fcount (3.238) > of Ftable (2.740) with a significance of 0.027 less than 0.05 .
\end{abstract}

Keywords: Competence; Teaching Style; Motivation; Achievement.

How to cite: Kusjono, G. \& Suprianto (2020), Pengaruh Kompetensi, Gaya Mengajar dan Motivasi terhadap Prestasi Mahasiswa Journal of Education, Humaniora and Social Sciences (JEHSS). 3(2) 620-628 
Gatot Kusjono \& Suprianto, Pengaruh Kompetensi, Gaya Mengajar dan Motivasi terhadap Prestasi

\section{PENDAHULUAN}

Pembukaan Undang-Undang Dasar 1945 alinia keempat mengamanatkan pemerintah Indonesia salah satunya adalah mencerdaskan kehidupan bangsa. Hal ini memberikan arti bahwa pemerintah memberikan perhatian yang serius terhadap dunia pendidikan baik itu pada jendajng pendidikan dasar, menengah maupun perguruan tinggi. Pendidikan merupakan titik sentral untuk mewujudkan Sumber Daya Manusia (SDM) berkualitas yang mampu untuk beradaptasi dengan perkembangan zaman. Pendidikan merupakan usaha sadar dan terencana untuk mewujudkan suasana belajar dan proses pembelajaran agar peserta didik secara aktif mengembangkan potensi dirinya untuk memiliki kekuatan spiritual keagamaan, pengendalian diri, kepribadian, kecerdasan, akhlak mulia, serta ketrampilan yang diperlukan dirinya, masyarakat bangsa dan negara Indonesia (Pasal 1 Ayat (1) UU Nomor 20 Tahun 2003 Tentang Sistem Pendidikan Nasional).

Prestasi terbaik dalam pendidikan merupakan tujuan akhir yang selalu ingin dicapai peserta didik baik dalam jenjang pendidikan dasar, menengah maupun perguruan tinggi. Keberhasilan pencapaian tujuan pendidikan juga diikuti dengan terbentuknya peserta didik yang juga memiliki akhlaq mulia dan mampu bersaing di era globalisasi saat ini. Tujuan ini sesuai dengan Sistem Pendidikan Nasional, Undang-Undang No.20 tahun 2003 yang menyatakan "Pendidikan Nasional berfungsi mengembangkan kemampuan dan membentuk watak serta peradaban bangsa yang bermartabat dalam rangka mencerdaskan kehidupan bangsa, bertujuan untuk berkembangnya potensi peserta didik agar menjadi manusia yang beriman dan bertakwa kepada Tuhan Yang Maha Esa, berakhlak mulia, sehat, berilmu, cakap, kreatif, mandiri, dan menjadi warga negara yang demokratis serta bertanggungjawab"(Indrawan et al., 2020).

Jenjang pendidikan di perguruan tinggi hendaknya dapat meningkatkan kualitas pendidikannya dengan cara membekali peserta didiknya dengan keahlian dan keterampilan sesuai dengan disiplin ilmu yang ditekuninya. Sehingga lulusannya akan menjadi sumberdaya manusia berkualitas yang sesuai dengan kebutuhan dan perkembangan dunia kerja saat ini. Sesuai UU RI No. 20 Tahun 2003, Bab I Pasal 1 disebutkan: "Pendidikan adalah usaha sadar dan terencana untuk mewujudkan suasana belajar dan proses pembelajaran agar peserta didik secara aktif mengembangkan potensi dirinya untuk memiliki kekuatan spiritual keagamaan, pengendalian diri, kepribadian, kecerdasan, akhlak mulia, serta keterampilan yang diperlukan dirinya, masyarakat, bangsa dan negara".

Keberhasilan pendidikan di perguruan tinggi, selain ditentukan oleh kualitas kompetensi tenaga pendidik (dosen) yang meliputi: 1) kompetensi pedagogik; 2) kompetensi kepribadian; 3) kompetensi sosial; dan 4) kompetensi professional. Selain keempat kompetensi tersebut dalam penyampaian materi pendidik/dosen juga dituntut untuk menguasai gaya mengajar atau teaching style. Gaya mengajar merupakan metode yang digunakan pendidik ketika sedang melakukan proses pembelajaran atau perkuliahan. (Hasanuddin, 2019; Hasanuddin, 2020; Cece, 2019; Wijoyo et al., 2020). Gaya mengajar bukan hanya pesan di dalam kelas saja, akan tetapi bagaimana dalam penyampain materi yang menarik akan memotivasi peserta pembelajaran dapat lebih fokus dan konsentrasi terhadap jalannya proses pembelajan (Gede et al., 2020).

Keberhasilan pencapaian tujuan pendidikan selain ditentukan oleh pendidik atau pengajar, juga ditentukan dan dipengaruhi pula oleh faktor peserta didik/mahasiswa itu sendiri. Faktor yang sangat berperan dalam pencapaian tujuan pendidikan dalam hal ini prestasi yang baik, sangat ditentukan pula oleh motivasi mahasiswa dalam mengikuti kegiatan pembelajaran. (Metia, \& Fenty, 2012; Wati \& Meutia, 2010; Metia, \& Fenty, 2012; Silfiyani, 2018)

Motivasi tersebut bisa berasal dari dalam individu itu sendiri (instrinsik) maupun yang berasal dari luar individu (ekstrinsik). Motivasi intrinsik merupakan kebutuhan dan dorongan yang berkaitan dengan kegiatan pembelajaran dimulai dan diteruskan berdasarkan penghayatan aktivitas belajar (Suarjana et al., 2017; Sunarsi, 2020; Winata, 2019; Yuangga, \& Sunarsi, 2018). Sedangkan motivasi ekstrinsik merupakan kegiatan belajar yang tumbuh dari dorongan dan kebutuhan seseorang dikarenakan adanya motif-motif aktif dikarenakan perangsang dari luar, 
seperti memperoleh pekerjaan yang lebih baik dan karir di tempat kerja akan meningkat (Wijoyo \& Girivirya, 2020).

\section{METODE PENELITIAN}

Desain penelitian yang digunakan adalah desain penelitian kausal, riset kausal yang tujuan utamanya adalah mendapatkan bukti mengenai hubungan sebab akibat (Malhotra: 2009). Riset kausal disebut sebagai riset konklusif dikarenakan memuat kesimpulan akhir (conclusif) dari hasil temuan. Selanjutnya pada penelitian ini variabel bebas mempengaruhi variabel terikat. Hal ini dikarenakan penelitian ini bertujuan untuk mengetahui pengaruh antara variabel bebas $(\mathrm{X})$ terhadap variabel terikat (Y) yang kemudian akan diambil sebuah kesimpulan.

Populasi dalam penelitian adalah seluruh mahasiswa peserta perkuliahan statistik-1 dan matematika ekonomi Reguler C, yang diampu oleh dosen peneliti dengan jumlah 247 mahasiswa. Adapun sampel yang diambil sebanyak 72 responden, menggunakan rumus slovin.

\section{HASIL DAN PEMBAHASAN}

"Uji validitas digunakan untuk mengukur valid atau tidaknya suatu instrumen. Suatu kuesioner dikatakan valid apabila pertanyaan/butir mampu mengungkapkan sesuatu yang akan diukur oleh kuesioner tersebut" (Menurut Husein Umar:2009). Instrumen dikatakan valid jika

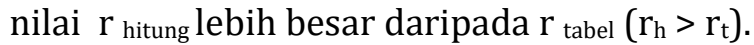

Tabel 2. Hasil Uji Validitas Instrumen Variabel Penelitian

\begin{tabular}{lllll}
\hline No & Instrumen Variabel & $\mathrm{r}_{\text {hitung }}$ & $\mathrm{r}_{\text {tabel }}$ & Validitas \\
\hline A & Variabel Kompetensi Pendidik $\left(\mathbf{X}_{\mathbf{1}}\right)$ & & \\
\hline 1 & Komp-1 & $.655^{* *}$ & 0,2303 & Valid \\
\hline 2 & Komp-2 & $.740^{* *}$ & 0,2303 & Valid \\
\hline 3 & Komp-3 & $.739^{* *}$ & 0,2303 & Valid \\
\hline 4 & Komp-4 & $.777^{* *}$ & 0,2303 & Valid \\
\hline 5 & Komp-5 & $.809^{* *}$ & 0,2303 & Valid \\
\hline 6 & Komp-6 & $.726^{* *}$ & 0,2303 & Valid \\
\hline 7 & Komp-7 & $.767^{* *}$ & 0,2303 & Valid \\
\hline 8 & Komp-8 & $.747^{* *}$ & 0,2303 & Valid \\
\hline B & Variabel Gaya Mengajar & $\left.\mathbf{X}_{2}\right)^{* *}$ & & \\
\hline 1 & Gaya-1 & $.551^{* *}$ & 0,2303 & Valid \\
\hline 2 & Gaya-2 & $.488^{* *}$ & 0,2303 & Valid \\
\hline 3 & Gaya-3 & $.477^{* *}$ & 0,2303 & Valid \\
\hline 4 & Gaya-4 & $.643^{* *}$ & 0,2303 & Valid \\
\hline 5 & Gaya-5 & $.701^{* *}$ & 0,2303 & Valid \\
\hline 6 & Gaya-6 & $.733^{* *}$ & 0,2303 & Valid \\
\hline 7 & Gaya-7 & $.741^{* *}$ & 0,2303 & Valid \\
\hline 8 & Gaya-8 & $.764^{* *}$ & 0,2303 & Valid \\
\hline 9 & Gaya-9 & $.727^{* *}$ & 0,2303 & Valid \\
\hline 10 & Gaya-10 & $.712^{* *}$ & 0,2303 & Valid \\
\hline 11 & Gaya-11 & $.800^{* *}$ & 0,2303 & Valid \\
\hline 12 & Gaya-12 & $.837^{* *}$ & 0,2303 & Valid \\
\hline C & Variabel Motivasi Mahasiswa $\left(\mathbf{X}_{3}\right)$ & & \\
\hline 1 & Mot-1 & $.701^{* *}$ & 0,2303 & Valid \\
\hline 2 & Mot-2 & $.810^{* *}$ & 0,2303 & Valid \\
\hline 3 & Mot-3 & $.641^{* *}$ & 0,2303 & Valid \\
\hline & & & \\
\hline
\end{tabular}


Gatot Kusjono \& Suprianto, Pengaruh Kompetensi, Gaya Mengajar dan Motivasi terhadap Prestasi Mahasiswa

\begin{tabular}{lllll}
\hline No & Instrumen Variabel & $\mathrm{r}_{\text {hitung }}$ & $\mathrm{r}_{\text {tabel }}$ & Validitas \\
\hline 4 & Mot-4 & $.643^{* *}$ & 0,2303 & Valid \\
\hline 5 & Mot-5 & $.763^{* *}$ & 0,2303 & Valid \\
\hline 6 & Mot-6 & $.709^{* *}$ & 0,2303 & Valid \\
\hline 7 & Mot-7 & $.688^{* *}$ & 0,2303 & Valid \\
\hline 8 & Mot-8 & $.815^{* *}$ & 0,2303 & Valid \\
\hline 9 & Mot-9 & $.789^{* *}$ & 0,2303 & Valid \\
\hline 10 & Mot-10 & $.669^{* *}$ & 0,2303 & Valid \\
\hline 11 & Mot-11 & $.697^{* *}$ & 0,2303 & Valid \\
\hline 12 & Mot-12 & $.652^{* *}$ & 0,2303 & Valid \\
\hline 13 & Mot-13 & $.476^{* *}$ & 0,2303 & Valid \\
\hline
\end{tabular}

Dari tabel di atas, karena semua butir pernyataan dinyatakan valid karena semua itemitem pernyataan memiliki nilai $r_{\text {hitung }}$ lebih besar dari nilai $r_{\text {tabel }}(0,2303)$.

\section{Uji Reliabilitas}

Uji reliabilitas berguna untuk menetapkan apakah instrument dalam hal ini kuesioner dapat digunakan lebih dari satu kali. "Suatu konstruks dikatakan reliabel apabila memberikan nilai Alpha-Cronbach $>0.60$.

Tabel 3. Hasil Uji Reliabilitas

\begin{tabular}{lll}
\hline Variabel & Cronbach's Alpha & Simpulan \\
\hline Kompetensi Pendidik $\left(\mathrm{X}_{1}\right)$ & 0.884 & Reliabel \\
\hline Gaya Mengajar $\left(\mathrm{X}_{2}\right)$ & 0.881 & Reliabel \\
\hline Motivasi Mahasiswa $\left(\mathrm{X}_{3}\right)$ & $0 ., 905$ & Reliabel \\
\hline
\end{tabular}

Karena nilai seluruh nilai Cronbach's Alpha lebih besar dari 0,60, maka seluruh instrumen penelitian reliabel digunakan untuk mengumpulkan data penelitian.

Uji Normalitas

Pengujian normalitas menggunakan nilai Asymp.Sig. (2-tailed) dengan kriteria apabila sig. ( 2 tailed) $>0.05$, dinyatakan bahwa data berasal dari populasi yang berdistribusi normal (Sudarmanto, 2015).

Tabel 4.Hasil Uji Normalitas

One-Sample Kolmogorov-Smirnov Test

\begin{tabular}{lll}
\hline & & ABS_RES \\
\hline $\mathrm{N}$ & & 72 \\
Normal Parameters & Mean & 3.0790 \\
& Std. Deviation & 1.87785 \\
Most Extreme Differences & Absolute & .125 \\
& Positive & .125 \\
Kolmogorov-Smirnov Z & Negative & -.089 \\
Asymp. Sig. (2-tailed) & & $\mathbf{1 . 0 5 9}$ \\
\hline
\end{tabular}

a. Test distribution is Normal.

b. Calculated from data.

Sumber : hasil olahan SPSS, 2020

Dari hasil pengujian diperoleh angka sig. 0,212 lebih besar dari $0.05(>5 \%)$, dengan demikian sebaran data residual berdistribusi normal. Sehingga bisa dikatakan dalam hal ini datadata tersebut baik untuk dianalisis lebih lanjut karena data berasal dari populasi yang berdistribusi secara normal. 
Uji heteroskedastisitas bertujuan untuk menguji apakah dalam model regresi terjadi ketidaksamaan varian dari residual dari satu pengamatan ke pengamatan yang lain. Model regresi yang baik, jika tidak terjadi heteroskedastisitas jika nilai signifikansinya lebih besar dari 0,05 .

Tabel 5. Hasil Uji Heteroskedastisitas Coefficients $^{\mathrm{a}}$

\begin{tabular}{|c|c|c|c|c|c|c|}
\hline \multirow{2}{*}{\multicolumn{2}{|c|}{ Model }} & \multicolumn{3}{|c|}{ Unstandardized Coefficients Standardized Coefficients } & \multirow[t]{2}{*}{$\mathrm{t}$} & \multirow[t]{2}{*}{ Sig. } \\
\hline & & $\mathrm{B}$ & Std. Error & Beta & & \\
\hline & (Constant) & 3.088 & 2.083 & & 1.482 & .143 \\
\hline \multirow{3}{*}{1} & Kompetensi & 045 & 096 & .079 & 471 & 639 \\
\hline & Gaya Mengajar & .026 & .104 & .059 & .249 & .804 \\
\hline & Motivasi & -.054 & .083 & -.140 & -.643 & .522 \\
\hline
\end{tabular}

a. Dependent Variable: ABS_RES

Berdasarkan tabel di atas diperoleh nilai signifikansi lebih besar dari 0,05, berarti tidak terjadi heterokedatisitas pada model regresi sehingga model regresi layak dipakai untuk prediksi variabel prestasi.

Uji Multikolonieritas bertujuan untuk menguji apakah model regresi ditemukan adanya korelasi antar variabel bebas (independent).

Tabel 6.Hasil uji Multikolonieritas

\begin{tabular}{|c|c|c|c|}
\hline & \multirow[t]{2}{*}{ Model } & \multicolumn{2}{|c|}{ Collinearity Statistics } \\
\hline & & Tolerance & VIF \\
\hline \multirow{4}{*}{1} & (Constant) & & \\
\hline & Kompetensi & .513 & 1.949 \\
\hline & Gaya Mengajar & .256 & 3.910 \\
\hline & Motivasi & .310 & 3.229 \\
\hline
\end{tabular}

Dari tabel di atas menunjukan bahwa nilai VIF seluruh variabel lebih kecil dari 10 dan nilai tolerance variabel independen semuanya lebih kecil dari 1,0 sehingga tidak ada masalah multikolinearitas.

Analisis Regresi Linier Berganda

Hasil uji regresi berganda seperti ditunjukkan pada table berikut:.

Tabel 7. Regresi Linier Berganda Pengaruh Variabel Kompetensi, Gaya Mengajar dan Motivasi Mahasisa terhadap Prestasi Mahasiswa

\begin{tabular}{cccc}
\hline Variabel & Koefisien & t $_{\text {hitung }}$ & Sig. \\
\hline Konstanta & 69.115 & 17.113 & .000 \\
\hline Kompetensi Pendidik & .252 & 1.349 & .182 \\
\hline Gaya Mengajar & -.582 & -2.879 & .005 \\
\hline Motivasi Mahasiswa & .428 & 2.647 & .010 \\
\hline $\mathrm{R}$ & 0,354 & &
\end{tabular}

Berdasarkan Tabel 4.15. di atas, maka diperoleh persamaan regresi linier berganda $\quad \mathrm{Y}=$ $69,115+0,252 X_{1}-0,548 X_{2}+0,428 X_{3}$.

Dari persamaan di atas dapat dijelaskan sebagai berikut :

Angka konstanta 69,115 menyatakan apabila nilai variabel kompetensi, gaya dan motivasi mahasiswa mengajar konstan (0) maka prestasi mahasiswa sudah mempunyai nilai sebesar 69,115 . Nilai konstanta positif, artinya apabila ada upaya yang baik pada kompetensi, gaya mengajar dan motivasi mahasiswamaka prestasi mahasiswa akan mengalami peningkatan.

Nilai Koefisien regresi 0,252 pada variabel kompetensi adalah bernilai positif menyatakan bahwa dengan mengasumsikan ketiadaan variabel independen lainnya, maka apabila variabel 
Gatot Kusjono \& Suprianto, Pengaruh Kompetensi, Gaya Mengajar dan Motivasi terhadap Prestasi

\section{Mahasiswa}

kompetensi mengalami peningkatan satu tingkat, maka variabel prestasi mahasiswa juga akan mengalami peningkatan sebesar 0,252 kali atas setiap penambahan yang terjadi pada variabel kompetensi pendidik.

Nilai Koefisien regresi 0,582 pada variabel gaya mengajar adalah bernilai negatif menyatakan bahwa dengan mengasumsikan ketiadaan variabel independen lainnya, maka apabila variabel gaya mengajar mengalami peningkatan satu tingkat, maka variabel prestasi mahasiswa juga akan mengalami penurunan sebesar 0,282 kali atas setiap penambahan yang terjadi pada variabel kompetensi pendidik.

Nilai koefisien regresi 0,428 pada variabel motivasi mahasiswa adalah bernilai positif menyatakan bahwa dengan mengasumsikan ketiadaan variabel independen lainnya, maka apabila variabel mptivasi mahasiswa mengalami peningkatan satu tingkat, maka variabel prestasi mahasiswa juga akan mengalami peningkatan sebesar 0,428 kali atas setiap penambahan yang terjadi pada variabel kompetensi pendidik.

Koefisien determinasi simultan adalah suatu besaran yang mengukur tingkat keeratan hubungan variabel-variabel bebas secara simultan terhadap kinerja karyawan yang disajikan pada tabel berikut:

Tabel 8. Hasil Perhitungan Koefisien Korelasi Dan Determinasi Simultan

\begin{tabular}{ccccc}
\hline Model & $\mathrm{R}$ & $\mathrm{R}$ Square & Adjusted R Square & Std. Error of the Estimate \\
\hline 1 & $.354^{\mathrm{a}}$ & .125 & .086 & 3.70405 \\
\hline \multicolumn{5}{c}{ a. Predictors: (Constant), Motivasi, Kompetensi, Gaya Mengajar } \\
b. Dependent Variable: Prestasi
\end{tabular}

Berdasarkan tabel di atas, nilai koefisien determinasi berganda atau Adjusted $R$ squared sebesar 0,086 atau 8,6\%. Berarti kontribusi secara simultan variabel bebas yaitu kompetensi, gaya mengajar dan motivasi adalah sebesar $8,6 \%$ terhadap variabel terikat prestasi mahasiswa. Sedangkan sisanya sebesar $91,4 \%$ dipengaruhi oleh variabel lain yang tidak termasuk dalam model regresi linier berganda.

Pengujian parsial (Uji t) bertujuan untuk melihat seberapa jauh pengaruh variabel bebas (kompetensi, gaya mengajar dan motivasi) terhadap variabel terikat (prestasi) secara parsial.

Hipotesis yang akan diuji pada bagian ini adalah:

$\mathrm{H}_{0}: ß 1=0$, dimana $\mathrm{i}=1,2$ secara parsial variabel bebas yang meliputi kompetensi, gaya mengajar dan motivasi tidak memberikan pengaruh yang signifikan terhadap prestasi mahasiswa Universitas Pamulang.

$\mathrm{H}_{1}: \quad \beta 1 \neq 0$, dimana $\mathrm{i}=1,2$ secara parsial variabel bebas yang meliputi kompetensi, gaya mengajar dan motivasi memberikan pengaruh yang signifikan terhadap motivasi mahasiswa Universitas Pamulang.

Hasil uji parsial seperti ditunjukkan pada tabel 4.18 berikut:

\begin{tabular}{ccccc}
\multicolumn{5}{c}{ Tabel 9. Hasil Uji Parsial (Uji t) } \\
\hline Variabel bebas & $\mathrm{t}_{\text {hitung }}$ & Sig & Ho & H1 \\
\hline Kompetensi & $\mathbf{1 , 3 4 9}$ & $\mathbf{0 , 1 8 2}$ & Diterima & Ditolak \\
Gaya Mengajar & $\mathbf{- 2 , 8 7 9}$ & $\mathbf{0 , 0 0 5}$ & Ditolak & Diterima \\
Motivasi & $\mathbf{2 , 6 4 7}$ & 0,010 & Ditolak & Diterima \\
\hline
\end{tabular}

Sumber: Pengolahan data (2020)

Berdasarkan hasil uji parsial pada tabel 4.17 di atas dapat diketahui:

Nilai $t_{\text {hitung }}$ untuk variabel kompetensi sebesar 0,727 , sedangkan nilai $t_{\text {tabel }}$ untuk $\alpha(0,05)$ dan $\mathrm{db}=\mathrm{n}-\mathrm{k}=72-2=70$ diperoleh nilai $\mathrm{t}_{\text {tabel }}$ sebesar 1,994 dengan nilai tingkat signifikansi sebesar 0,182 $>\alpha(0,05)$. Karena $t_{\text {hitung }}(1,349)<t_{\text {tabel }}(1,994)>$ dan taraf signifikansi 0,182 $>0,05$ atau $5 \%$, dengan demikian $\mathrm{H}_{0}$ diterima dan $\mathrm{H}_{1}$ ditolak artinya variabel kompetensi pendidik secara parsial tidak memberikan pengaruh yang signifikan terhadap prestasi mahasiswa Universitas Pamulang.

Nilai $t_{\text {hitung }}$ untuk variabel kompetensi sebesar negatif 2,879, sedangkan nilai tabel sebesar 1,994 dengan nilai tingkat signifikansi sebesar $0,005<\alpha(0,05)$. Karena $t_{\text {hitung }}(2,879)>t_{\text {tabel }}$ $(1,994)>$ dan taraf signifikansi $0,005<0,05$ atau $5 \%$, dengan demikian $\mathrm{H}_{0}$ ditolak dan $\mathrm{H}_{1}$ 
diterima artinya variabel gaya mengajar secara parsial memberikan pengaruh yang signifikan terhadap prestasi mahasiswa Universitas Pamulang.

Nilai thitung untuk variabel kompetensi sebesar positif 2,647, sedangkan nilai $t_{\text {tabel }}$ sebesar 1,994 dengan nilai tingkat signifikansi sebesar $0,010<\alpha(0,05)$. Karena $t_{\text {hitung }}(2,647)>t_{\text {tabel }}$ $(1,994)>$ dan taraf signifikansi $0,010<0,05$ atau $5 \%$, dengan demikian $\mathrm{H}_{0}$ ditolak dan $\mathrm{H}_{1}$ diterima artinya variabel motivasi mahasiswa secara parsial memberikan pengaruh yang signifikan terhadap prestasi mahasiswa Universitas Pamulang.

Uji kelayakan model (Uji F) dilakukan untuk mengetahui apakah semua variabel independen yang dimasukkan dalam model mempunyai pengaruh secara simultan terhadap variabel dependen. Uji Statistik $F$ ini merupakan pengujian yang diperlukan dalam menguji hipotesis yang diajukan dalam penelitian ini yaitu:

$\mathrm{H}_{0}: \quad B 1=0$, secara simultan kompetensi, gaya mengajar dan motivasi tidak berpengaruh secara signifikan terhadap prestasi mahasiswa Universitas Pamulang.

$\mathrm{H}_{1}$ : $\quad B 1 \neq 0$, secara simultan kompetensi, gaya mengajar dan motivasi tidak berpengaruh secara signifikan terhadap prestasi mahasiswa Universitas Pamulang.

Sedangkan kriteria pengujiannya adalah:

Ho diterima apabila $F_{\text {hitung }}<\mathrm{F}_{\text {tabel }}$ atau Signifikansi $\mathrm{F}_{\text {hitung }}>\alpha$

Ho ditolak apabila $F_{\text {hitung }}>F_{\text {tabel }}$ atau Signifikansi $F_{\text {hitung }}<\alpha$

Hasil uji kelayakan model seperti ditunjukkan pada tabel 4.19.

Tabel 1o. Hasil Uji Kelayakan Model (Uji F)

\begin{tabular}{ccccc}
\hline $\mathrm{F}_{\text {hitung }}$ & $\mathrm{F}_{\text {tabel }}$ & Sig & Ho & H1 \\
\hline 3,238 & 2,740 & 0,027 & Ditolak & Diterima \\
\hline
\end{tabular}

Sumber: Pengolahan data (2020)

Dari tabel 4.18, diperoleh nilai $\mathrm{F}_{\text {hitung }}$ sebesar 3,238 sedangkan untuk nilai $\mathrm{F}_{\text {tabel }}$ dengan taraf signifikansi $5 \%$ dan derajat kebebasan $(\mathrm{dk})$ pembilang $=\mathrm{k}$ (banyak variabel bebas) $=3 \mathrm{dan} \mathrm{dk}$ penyebut $=\mathrm{n}-\mathrm{k}-1=72-3-1=68$ diperoleh $\mathrm{F}_{\text {tabel }}=2,740$. Jika nila $\mathrm{F}_{\text {hitung }}$ dibandingkan dengan $F_{\text {tabel }}$ maka $F_{\text {hitung }}(3,238)>$ dari $F_{\text {tabel }}(2,740)$ dengan tingkat signifikansi atau probabilitas $(\alpha)$ $0,027<0,05$, sehingga Ho ditolak dan Ha diterima. Hal ini berarti secara simultan kompetensi, gaya mengajar dan motivasi berpengaruh signifikan terhadap prestasi mahasiswa Universitas Pamulang.

Pengaruh Kompetensi (X1) terhadap Prestasi Mahasiswa (Y) Universitas Pamulang. Hasil uji parsial pengaruh kompetensi terhadap prestasi mahasiswa Universitas Pamulang, diperoleh nilai thitung $(1,349)<$ ttabel $(1,994)$ dan taraf signifikansi $0,182>0,05$ atau $5 \%$, dengan demikian H0 diterima dan $\mathrm{H} 1$ ditolak artinya variabel kompetensi secara parsial tidak memberikan pengaruh yang signifikan terhadap prestasi mahasiswa Universitas Pamulang. Hasil penelitian ini tidak sejalan dengan Murti dan Prasetio (2018) dan sejalan dengan Suarjana dan Yintayani (2017) yang meneliti tentang pengaruh kompetensi dosen terhadap prestasi belajar mahasiswa.

Pengaruh Gaya Mengajar (X2) terhadap Prestasi Mahasiswa (Y) Universitas Pamulang. Hasil uji parsial pengaruh gaya mengajar terhadap prestasi mahasiswa Universitas Pamulang diperoleh nilai thitung $(2,879)<\operatorname{ttabel}(1,994)$ dan taraf signifikansi $0,005>0,05$ atau $5 \%$, dengan demikian $\mathrm{H} 0$ ditolak dan $\mathrm{H} 1$ diterima artinya variabel gaya mengajar secara parsial memberikan pengaruh yang signifikan terhadap prestasi mahasiswa Universitas Pamulang. Hasil penelitian ini sejalan dengan Silfiyani (2018), Winata, C. E. (2019) dan Cece (2019) bahwa gaya mengajar dosen secara parsial berpengaruh positif dan signifikan terhadap prestasi mahasiswa.

Pengaruh Motivasi (X3) terhadap Prestasi Mahasiswa (Y) Universitas Pamulang.Hasil uji parsial pengaruh motivasi terhadap prestasi mahasiswa Universitas Pamulang, diperoleh nilai thitung $(2,647)<$ ttabel $(1,994)$ dan taraf signifikansi $0,010>0,05$ atau $5 \%$, dengan demikian $\mathrm{H} 0$ ditolak dan $\mathrm{H} 1$ diterima artinya variabel motivasi secara parsial tidak memberikan pengaruh yang signifikan terhadap prestasi mahasiswa Universitas Pamulang. Hasil penelitian ini sejalan dengan Silfiyani (2018), Winata, C. E. (2019) dan Cece (2019) bahwa motivasi mahasiswa secara parsial berpengaruh positif dan signifikan terhadap prestasi mahasiswa. 
Gatot Kusjono \& Suprianto, Pengaruh Kompetensi, Gaya Mengajar dan Motivasi terhadap Prestasi Mahasiswa

Pengaruh Pengaruh Kompetensi, Gaya Mengajar dan Motivasi terhadap Prestasi Mahasiswa Universitas Pamulang. Hasil perhitungan regresi linier berganda diperoleh persamaan linier berganda $Y=69,115+0,252 \mathrm{X}_{1}-0,548 \mathrm{X}_{2}+0,428 \mathrm{X}_{3}$. Dengan nilai konstanta positif, artinya apabila tidak ada upaya yang baik terhadap kompetensi, gaya mengajar dan motivasi maka prestasi mahasiswa sudah bernilai positif sebesar 69,115. Hasil pengujian simultan diperoleh nilai $F_{\text {hitung }}(3,238)>$ dari $F_{\text {tabel }}(2,740)$ dengan tingkat signifikansi atau probabilitas $(\alpha) 0,027<$ 0,05 artinya Ho ditolak dan Ha diterima. Sehingga dapat disimpulkan bahwa secara simultan kompetensi, gaya mengajar dan motivasi berpengaruh signifikan terhadap prestasi mahasiswa Universitas Pamulang. Adapun tingkat konstribusi dari variabel kompetensi, gaya mengajar dan motivasi terhadap prestasi mahasiswa Universitas Pamulang. oleh koefisien determinasi (KD) atau Adjusted $R$ sebesar 0,485 atau 48,5\% artinya varian prestasi mahasiswa ditentukan oleh variabel kompetensi, gaya mengajar dan motivasi dengan nilai sebesar 8,60\%. Sedangkan sisanya atau sebesar $91,40 \%$ itu ditentukan oleh variabel lain yang tidak diteliti.

\section{SIMPULAN}

Berdasarkan hasil Kompetensi pendidik secara parsial tidak memberikan pengaruh yang signifikan terhadap prestasi mahasiswa Universitas Pamulang, dengan hasil uji parsial $\mathrm{t}$ diperoleh nilai $t_{\text {hitung }}(1,349)<t_{\text {tabel }}(1,994)$ dan taraf signifikansi 0,182 $>0,05$ atau 5\% sehingga $\mathrm{H}_{0}$ diterima dan $\mathrm{H}_{1}$ ditolak. Gaya mengajar secara parsial memberikan pengaruh yang signifikan terhadap prestasi mahasiswa Universitas Pamulang dengan hasil uji t diperoleh nilai $\mathrm{t}_{\text {hitung }}$ $(2,879)<t_{\text {tabel }}(1,994)$ dan taraf signifikansi $0,005>0,05$ atau $5 \%$, sehingga $\mathrm{H}_{0}$ ditolak dan $\mathrm{H}_{1}$ diterima. Motivasi secara parsial tidak memberikan pengaruh yang signifikan terhadap prestasi mahasiswa Universitas Pamulang, dengan hasil uji t diperoleh nilai $t_{\text {hitung }}(2,647)<t_{\text {tabel }}(1,994)$ dan taraf signifikansi $0,010>0,05$ atau $5 \%$, sehingga $\mathrm{H}_{0}$ ditolak dan $\mathrm{H}_{1}$ diterima. Kompetensi, gaya mengajar dan motivasi secara simultan berpengaruh signifikan terhadap prestasi mahasiswa Universitas Pamulang. Hal ini diperkuat dengan persamaan regresi berganda $\mathrm{Y}=$ $69,115+0,252 X_{1}-0,548 X_{2}+0,428 X_{3}$. Hasil pengujian simultan diperoleh nilai $F_{\text {hitung }}(3,238)>$ dari $\mathrm{F}_{\text {tabel }}(2,740)$ dengan tingkat signifikansi atau probabilitas $(\alpha) 0,027<0,05$ artinya Ho ditolak dan Ha diterima.

\section{DAFTAR PUSTAKA}

Gede, I., Suci, S., Suyanta, W., Darna, W., Wijoyo, H., \& Setyawati, E. (2020). A MEASURE OF EFFECTIVENESS LEVEL OF ONLINE LEARNING AMID COVID-19 PANDEMIC IN THE COURSE OF THE PROJECT MANAGEMENT INFORMATION SYSTEMS (CASE STUDY IN STIKOM YOS SUDARSO PURWOKERTO). In Journal of Critical Reviews (Vol. 7, Issue 12). https://doi.org/10.31838/jcr.07.12.586

Indrawan, I., Wijoyo, H., Muliansyah, D., Sunarsi, D., Muhammad Lutfi, A., Irawati, L., Maduningtias, L., Hanny, R., Khoiri, A., Santamoko, R., \& Leo Handoko, A. (2020). PEMBELAJARAN DI ERA NEW NORMAL (Vol. 1).

Wijoyo, H., \& Girivirya, S. (2020). PENGARUH SEKOLAH MINGGU BUDDHA (SMB) TERHADAP PERKEMBANGAN FISIK-MOTORIK PESERTA DIDIK DI SMB SARIPUTTA BUDDHIST STUDIES PEKANBARU. Jurnal Maitreyawira, 1(1). https://maitreyawira.e-journal.id/jm/article/view/18

UU Nomor 20 Tahun 2003 Tentang Sistem Pendidikan Nasional).

Metia, C., Fenty Z., (2012), Hubungan Dukungan Sosial Orangtua dan Motivasi Belajar dengan Kemandirian Belajar, Analitika: 4 (1): 16-23

Wati S, P., Cut M., (2010), Hubungan antara Dukungan Sosial Keluarga dan Self Efficacy dengan Kemandirian Belajar pada Siswa SMKN 2 Medan, Analitika: 2 (2): 45-54

Metia, C., Fenty Z., (2012), Hubungan Dukungan Sosial Orangtua dan Motivasi Belajar dengan Kemandirian Belajar, Analitika: 4 (1): 16-23

Hasanuddin (2019). Perbedaan Gaya Berpikir Dosen Universitas Islam Sumatera Utara Medan. Journal of Education, Humaniora, and Social Sciences (JEHSS), 2 (1): 174-180.

Hasanuddin, H. (2020). Perbedaan Gaya Pengajaran Dosen Universitas Asahan Kisaran. Journal of Education, Humaniora and Social Sciences (JEHSS), 3(1), 141-146. doi:https://doi.org/10.34007/iehss.v3i1.218 
Cece, E. W. (2019). Pengaruh Gaya Mengajar Dosen dan Motivasi Belajar terhadap Prestasi Belajar Mahasiswa Perguruan Tinggi Swasta Kota Medan.Jurnal Penelitian Pendidikan Sosial Humaniora, 4(1), 448-454.

Wijoyo, H., Handoko, A.L., Santamoko, R., Sunarsi, D. (2020). Strategy model for character education through digital media for courses and training participants. E-prosiding pascasarjana universitas negeri gorontalo, 1-8

Silfiyani, N. (2018). Pengaruh Gaya Mengajar Dosen Dan Motivasi Belajar Terhadap Prestasi Akademik Mahasiswa Jurusan Manajemen Pendidikan Fakultas Ilmu Pendidikan Universitas Negeri Surabaya. Inspirasi Manajemen Pendidikan, 6(2).

Suarjana, A. A. G. M., \& Yintayani, N. N. (2017). Pengaruh Kompetensi Dosen Terhadap Prestasi Belajar Mahasiswa Pada Jurusan Akuntansi Politeknik Negeri Bali. Jurnal Bisnis Dan Kewirausahaan, 13(2), 87.

Sunarsi, D. (2020). Panduan Meningkatkan Kinerja Dan Kepuasan Guru. Kota Serang: Desanta Muliavisitama

Winata, C. E. (2019) Pengaruh Gaya Mengajar Dosen dan Motivasi Belajar terhadap Prestasi Belajar Mahasiswa Perguruan Tinggi Swasta Kota Medan.Jurnal Penelitian Pendidikan Sosial Humaniora, 4(1), 448-454.

Yuangga, K. D., \& Sunarsi, D. (2018). The Influence of Procrastination and Low Time Management on Student Self Efficacy (at MA Soebono Mantofani). PINISI Discretion Review, 2(1), 85-92. 